\title{
Effect of Eruca Sativa in Broiler Diet on Productivity
}

\author{
Ibrheem Eryan Ibrhim ${ }^{1}$, Mahdi. A. Al-Shuwaili' ${ }^{1}$, Bushra M.W. AL-Obaidi' ${ }^{2}$, Hayder R. Abed ${ }^{1}$ \\ ${ }^{1}$ Lecturer, Department of Public Health, Faculty of Veterinary Medicine, University of Kufa, Iraq, ${ }^{2}$ Lecturer, Dr, \\ Department of Public Health, Faculty of Veterinary Medicine, University of Fallujah
}

\begin{abstract}
This experiment was conducted on 120 unsexed Cobb chicks of one day old for 28 days. Chicks were randomly divided into 4 groups ( 30 chicks each) and each group consists of two replicates ( 15 chicks each). All groups was fed using a basal diet, but the first group drunk water from the tap as a control, while the other drunk water with extract of Eruca Sativa leaves $(0.25,0.50$ and $0.75 \mathrm{ml} / \mathrm{Liter})$ respectively. This study aimed to determine the effect of extraction of Eruca Sativa leaves on broiler performance, some blood parameters and immune response to Newcastle virus. The result showed that the supplementation of the broiler diet with extraction of Eruca sativa especially of levels $(0.25$ and $0.50 \mathrm{ml} / \mathrm{L})$ significantly improve the final body weight $(\mathrm{P} \leq 0.05)$. The weight gain also significantly improved $(\mathrm{P} \leq 0.05)$ but, there were no significantly changes in the weight of internal organs and blood pictures (WBCs, RBCs, $\mathrm{Hb}$ and PCV respectively). The antibody titer against the Newcastle virus found to be significantly increased $(\mathrm{P} \leq 0.05)$.
\end{abstract}

Keywords: Eruca sativa, broiler, performance, immunity.

\section{Introduction}

Using of antibiotics in animals feed as growth promoters have been implemented in poultry diets recently. Many studies attempted to find of alternative solutions which would provide positive effects on broiler growth and feed conversion ratio (FCR) ${ }^{(1)}$. Henceforth, essential oils have appeared as a possible alternative to antibiotics in the feed of animal (2). Eruca sativa (Rocket seed meal) locally known in Iraq as "Jarjeer" is containing vitamin C, carotenoids, some flavonoids (like luteolin and appin) and glucosinolates (the precursors of isothiocyanates and sulfaraphene) ${ }^{(3)}$. The Jarjeer is also contain $\mathrm{Cu}, \mathrm{Zn}, \mathrm{Fe}, \mathrm{Mn}, \mathrm{Mg}$ and other elements which are proposed as elements that enhances the immune system and the reproductive performance ${ }^{(4)}$. And as well as, increases plasma IgG concentration (5). Additionally, Bendich,et al., ${ }^{(6)}$ reported that Eruca sativa has a role in the enhancing of both $\mathrm{T}$ and $\mathrm{B}$ lymphocyte

\section{Corresponding Author:}

Ibrheem Eryan Ibrhim

Lecturer, Department of Public Health, Faculty of

Veterinary Medicine, University of Kufa, Iraq

e-mail: ibraheeme.ibraheem@uokufa.edu.iq proliferative responses and increase the production of certain interleukins .examples of some positive effects of essential oils are improving the feed conversion ratio (FCR) through increase the digestive enzymes secretion, appetite, positive stimulation of the immunity, increase vitality, antiviral and antioxidant activities, regulation the normal micro-flora in the intestine and finally, exhibit antimicrobial properties ${ }^{(7,8)}$. The essential oil (Eso) of Eruca sativa has therapeutic and medicinal properties ${ }^{(9)}$ It has been found that the extract of Eruca sativa exerts a prophylactic and a therapeutic role against oxidative stress by increasing the levels of antioxidant enzymes and antioxidant molecules $(10,11)$. The E sativa plays important role as antifungal and antimicrobial activity $(12,13)$. The aim of this study is to light the effects of adding Eruca sativa to the diet of the broiler by measuring the performance of the broilers, blood parameters and finally, immune responses of the Eruca sativa fed broiler to Newcastle disease.

\section{Material And Method}

A total number of 640 of unsexed broiler chicks (Cobb) aged 28 day-old were weighed and grouped randomly to 4 groups., Each group was additionally subdivided into two equal sub groups with 4 replicates (20 bird per each replicate). All the chickens were fed 
using similar starter (day 1-18 of age) and grower (day 18-28 of age) diets in a pellet form (Table 1). Only the water was enriched with the extraction of Eruca sativa and the broiler was irrigated as the following:

1. The first group was given ordinary water to be cosider as a control group.

2. The second group was irrigated using water with $0.25 \mathrm{ml} /$ litter of the extraction of Eruca sativa $(0.25$ $\mathrm{ml} /$ litter).

3. The third group was given water with $0.50 \mathrm{ml} /$ litter of the extraction of Eruca sativa.

4. The fourth group was given water with $0.75 \mathrm{ml} /$ litter of the extraction of Eruca sativa.

All the treatments (diets) were prepared and monitored daily. A vaccination against Bronchitis- virus was administrated to all the broiler on the first day (in drinking water), and a vaccination against Newcastle virus was also applied directly into the drinking water at 1st, 9th, 19th and 28th days of the experimental period. Finally, a vaccine against the Gumboro disease was also given by drinking water at the day 14th of the experiment. At the day 29th of age, three birds per group were randomly selected, weighed and postmortem examined by decapitation to collect some organs that are linked to the weights of the bird such as thyme, spleen and bursa of fabricius (to be used in analyzing the live body weight). Blood samples were collected from the heart directly at 1st, 9th, 19th and 28th days and stored in anticoagulant tubes (contain citrate sodium 3.6\% solution). Following a centrifugation (5000 rpm) for $7 \mathrm{~min}$, the serum was separated and at the consequent antibody-titer of Newcastle and Bronchitis disease viruses were measured using the ELISA technique. Performance of the broiler: - Weekly, weight gain, live body weight, feed intake and feed conversion ratio were calculated. Throughout the period, mortality was recorded of the study once it occurred. At the end of the experiment (three birds per group) were randomly selected, leg banded, weighed and slaughtered for carcass evaluation and obtained of internal organs (liver, spleen and bursa of fabricius).

Blood collection and evaluation: -At the end of four weeks of feeding with extraction of Eruca sativa, a one bird from each replicate was selected weekly, for blood collecting. Blood was collected by wing venipuncture from the right wing. Blood collection and serum separation: Blood was collected from each bird via brachial vein at days; 1st, 9th, 19th and 28th of age. Serum were separated, labeled and stored at $-20 \mathrm{C}$ until further analysis. ELISA procedure: - Batches of serum were subjected to serological test. Antibody titers against NDV were measured using ELISA technique described by (14) and NDV antibody test kit (Synbiotics Corporation, San Diego, USA).

\section{Table 1: Composition of experimental diet}

\begin{tabular}{|l|c|c|}
\hline Ingredients & Growing diet & Finishing diet \\
\hline Soy bean meal & 112.30 & 98.16 \\
\hline Full fat soybean & 200.00 & 200.00 \\
\hline Vitamin premix 1 & 2.00 & 2.00 \\
\hline Mineral premix 2 & 1.50 & 1.50 \\
\hline Salt & 1.65 & 1.48 \\
\hline Crud cotton oil & 25.64 & 27.98 \\
\hline Anticcociadial & 1.0 & 1.0 \\
\hline Antifungal & 2.0 & 2.0 \\
\hline Total calculate analysis & & \\
\hline Crude protein & 23.08 & 20.99 \\
\hline ME kcal/kg & 3338 & 3400 \\
\hline Calcium & 1.0 & 0.90 \\
\hline Available phosphorus & 0.48 & 0.48 \\
\hline Methionine + Cystine & 0.95 & 0.94 \\
\hline
\end{tabular}

\section{Results and Discussion}

Broiler performance: The results of Table 2 showed the effect of extract of Eruca sativa on live body weight. Interestingly, chicks that irrigated by a water supplemented with the extraction of Eruca sativa $0.25 \mathrm{ml} / \mathrm{L}$ had a significant higher body weight once they reached the third week $(p \leq 0.05)$ while there were no significant differences between groups at $1 \mathrm{st}, 2 \mathrm{nd}$ and $3 \mathrm{rd}$ week respectively compared with control. The current results showed the growth performance was improved in broiler that irrigated by a water containing different levels of essential oil especially the concentration 0.25 $\mathrm{ml} / \mathrm{L}$,Possible explanation could be that the extraction of the Eruca sativa may enhances the secretion of digestive enzymes which result in improving the digestion rate ${ }^{(17)}$. Furthermore, many studies indicated that the essential oils stimulate the activity and secretion of pancreatic enzymes such as amylase, lipase, chymotypsin and trypsin ${ }^{(18)(19)}$ reported that the essential oils of medical plants stimulate the digestion of proteins, fat and cellulose. 
Table 2: Effect of Eruca sativa on average live body weight of broiler per gram

\begin{tabular}{|c|c|c|c|c|c|}
\hline$\overbrace{\text { Treatment }}^{\text {Age }}$ & Hatching weight & Week 1 & Week 2 & Week 3 & Week 4 \\
\hline control & 40.6 & $165.4 \pm 1.69 \mathrm{a}$ & $398.0 \pm 3.65 \mathrm{a}$ & $654.7 \pm 9.64 b$ & $1163.0 \pm 25.96 \mathrm{c}$ \\
\hline $0.25 \mathrm{ml} / \mathrm{L}$ & 41.2 & $151.5 \pm 1.75 \mathrm{ab}$ & $380.5 \pm 5.49 b$ & $705.4 \pm 5.90 \mathrm{a}$ & $1278.0 \pm 11.77 \mathrm{~b}$ \\
\hline $0.50 \mathrm{ml} / \mathrm{L}$ & 43.1 & $148.6 \pm 1.69 b$ & $377.1 \pm 4.98 b$ & $662.1 \pm 8.80 \mathrm{~b}$ & $1277.2 \pm 10.90 \mathrm{~b}$ \\
\hline $0.75 \mathrm{ml} / \mathrm{L}$ & 43.3 & $153.6 \pm 1.70 \mathrm{ab}$ & $376.1 \pm 4.49 \mathrm{a}$ & $672.1 \pm 2.75 \mathrm{ab}$ & $1236.2 \pm 9.78 b$ \\
\hline
\end{tabular}

Values are means \pm standard error. Mean values Similar vertically no significant differences at the level of probability $(\mathrm{p}<0.05)$.

Table 3 showed the effect of extraction of Eruca sativa on weight gain of broiler, the main observation was the significant differences $(\mathrm{p} \leq 0.05)$ at 4 th week between all treatments and control as well as accumulative weight body gain. This could be due to high concentration of
Erucic acid that contributed to antimicrobial activity ${ }^{(13)}$. Thus, it was expected that the essential oils could have an effect on the gastrointestinal microflora by lowering the number of Escherichia coli and Clostridium perfringens and increased the number of Lactobacillus species.

Table 3: Effect of Eruca sativa on average weight gain of broiler per gram.

\begin{tabular}{|c|c|c|c|c|c|}
\hline Treatment Age & Week 1 & Week 2 & Week 3 & Week 4 & $\begin{array}{c}\text { Accumulative } \\
\text { body gain }\end{array}$ \\
\hline control & $125.4 \pm 1.69 \mathrm{a}$ & $242.6 \pm 4.15 \mathrm{a}$ & $286.7 \pm 7.53 \mathrm{a}$ & $498.3 \pm 20.36 \mathrm{~d}$ & $1.153 \pm 53.56 \mathrm{~b}$ \\
\hline $0.25 \mathrm{ml} / \mathrm{L}$ & $120.5 \pm 1.75 \mathrm{ab}$ & $230.0 \pm 6.55 \mathrm{a}$ & $340.9 \pm 6.89 \mathrm{a}$ & $576.6 \pm 14.14 b c$ & $1.268 \pm 44.18 \mathrm{a}$ \\
\hline $0.50 \mathrm{ml} / \mathrm{L}$ & $119.6 \pm 1.96 b$ & $227.5 \pm 4.30 \mathrm{a}$ & $315.0 \pm 6.82 b c$ & $605.1 \pm 16.83 \mathrm{ab}$ & $1.267 \pm 60.67 \mathrm{a}$ \\
\hline $0.75 \mathrm{ml} / \mathrm{L}$ & $154.6 \pm 1.70 \mathrm{ab}$ & $241.5 \pm 5.33 \mathrm{a}$ & $306.0 \pm 5.83 \mathrm{~cd}$ & $554.1 \pm 11.29 \mathrm{c}$ & $1.256 \pm 40.52 \mathrm{a}$ \\
\hline
\end{tabular}

Values are means \pm standard error. Mean values Similar vertically no significant differences at the level of probability $(\mathrm{p}<0.05)$.

Tables 4 and 5 showed significant effects of Eruca sativa on feed intake of broiler and feed conversion ratio from $3 \mathrm{rd}$ and 4 th weeks at 0.50 and $0.25 \mathrm{ml} / \mathrm{L}$ respectively. Indeed, there were no significant effects of the extraction of Eruca sativa $(p \leq 0.05)$ at 4 th week on feed intake. This could be explained by present more than one active ingredient in the herb and the effects are cumulative. Botsoglou et al,. $2002^{(20)}$ reported that the different levels of essential oil (20-200 ppm) in poultry diets. Positive effects like, weight gain and feed intake were increased whereas feed conversion ratio decreased as compared with control and this is corresponding to $(0.25$ and $0.50 \mathrm{ml} / \mathrm{L})$ these results are

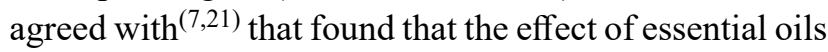
can be positively through improve feed conversion ratio through increase digestive enzymes secretion, appetite, stimulation of immunity, increased vitality, antiviral, antioxidant activity, regulation of the intestinal microflora and, they exhibit antimicrobial properties.

Table 4: Effect of Eruca sativa on average feed intake of broiler per gram

\begin{tabular}{|l|c|c|c|c|}
\hline Treatment Age & Week 1 & Week 2 & Week 3 & Week 4 \\
\hline Control & $100 \pm 0.01 \mathrm{a}$ & $440 \pm 0.08 \mathrm{a}$ & $510 \pm 0.01 \mathrm{~b}$ & $880 \pm 0.11 \mathrm{a}$ \\
\hline $0.25 \mathrm{ml} / \mathrm{L}$ & $130 \pm 0.01 \mathrm{a}$ & $520 \pm 0.02 \mathrm{a}$ & $510 \pm 0.04 \mathrm{~b}$ & $1180 \pm 0.05 \mathrm{a}$ \\
\hline $0.50 \mathrm{ml} / \mathrm{L}$ & $110 \pm 0.05 \mathrm{a}$ & $510 \pm 0.08 \mathrm{a}$ & $630 \pm 0.03 \mathrm{a}$ & $160 \pm 0.01 \mathrm{a}$ \\
\hline $0.75 \mathrm{ml} / \mathrm{L}$ & $120 \pm 0.01 \mathrm{a}$ & $480 \pm 0.04 \mathrm{a}$ & $540 \pm 0.01 \mathrm{ab}$ & $1130 \pm 0.06 \mathrm{a}$ \\
\hline
\end{tabular}

Values are means \pm standard error. Mean values Similar vertically no significant differences at the level of probability $(\mathrm{p}<0.05)$. 
Table 5: Effect of Eruca sativa on average feed conversion ratio of broiler per gram

\begin{tabular}{|c|c|c|c|c|}
\hline${ }_{\text {Treatment }}^{\text {Age }}$ & Week 1 & Week 2 & Week 3 & Week 4 \\
\hline Control & $0.790 .17 \mathrm{a}$ & $1.81 \pm 0.32 \mathrm{a}$ & $1.79 \pm 0.02 \mathrm{a}$ & $1.77 \pm 0.08 \mathrm{ab}$ \\
\hline $0.25 \mathrm{ml} / \mathrm{L}$ & $1.080 .15 \mathrm{a}$ & $2.26 \pm 0.24 \mathrm{a}$ & $1.50 \pm 0.01 \mathrm{~b}$ & $2.05 \pm 0.10 \mathrm{a}$ \\
\hline $0.50 \mathrm{ml} / \mathrm{L}$ & $0.91 \pm 0.03 \mathrm{a}$ & $2.24 \pm 0.49 \mathrm{a}$ & $2.0 \pm 0.05 \mathrm{a}$ & $0.26 \pm 0.02 b$ \\
\hline $0.75 \mathrm{ml} / \mathrm{L}$ & $0.86 \pm 0.15 \mathrm{a}$ & $2.07 \pm 0.12 \mathrm{a}$ & $1.85 \pm 0.14 \mathrm{ab}$ & $2.03 \pm 0.09 \mathrm{ab}$ \\
\hline
\end{tabular}

Values are means \pm standard error. Mean values Similar vertically no significant differences at the level of probability $(\mathrm{p}<0.05)$.

Internal organs and antibody titer: There were no significant differences in thyme, spleen and bursa percentage of chick irrigated with the extraction of Eruca sativa at $0.25,0.50$ and $0.75 \mathrm{ml} / \mathrm{L}$ (table 6 ). However, there were significant differences in antibodies titers at 9th and 28th days of broiler given a water with $0.75 \mathrm{ml} / \mathrm{L}$ of the extraction of Eruca sativa at 9th and $0.50 \mathrm{ml} / \mathrm{L}$ at 28 th. The negative effect in internal organs might be attributed to high concentration of essential oil and may be a great part of the components are metabolized and then precipitated in the chicken meat. These results agreed those obtained by ${ }^{(24)}$ and ${ }^{(24)}$. Both paper reported that the relative weight of some organs such as bursa and spleen, and also antibody titration against Newcastle virus had no significant differences between some herb extract and control. The enhanced in antibody titer may be result of the mineral content of $\mathrm{Cu}, \mathrm{Zn}, \mathrm{Fe}, \mathrm{Mn}, \mathrm{Mg}$ and other elements which may enhance the immune response and the reproductive performance ${ }^{(4)}$. Finally enhancing of both $\mathrm{T}$ and $\mathrm{B}$ lymphocytes responses and interleukins have been reported by ${ }^{(6)}$.

Table 6: Show the effect of Eruca sativa on internal organs weight of broiler at age 28 days.

\begin{tabular}{|l|c|c|c|}
\hline Treatment & Thyme weight \% & Spleen weight \% & Bursa weight \% \\
\hline Control & $0.35 \pm 0.07$ & $0.14 \pm 0.84$ & $0.19 \pm 0.01$ \\
\hline Mix 0.25\% & $0.41 \pm 0.13$ & $0.13 \pm 0.86$ & $0.17 \pm 0.02$ \\
\hline Mix 0.50\% & $0.46 \pm 0.09$ & $0.14 \pm 0.84$ & $0.19 \pm 0.02$ \\
\hline Thyme 0.25\% & $0.24 \pm 0.05$ & $0.12 \pm 0.87$ & $0.19 \pm 0.01$ \\
\hline
\end{tabular}

Values are means \pm standard error. Mean values Similar vertically no significant differences at the level of probability $(\mathrm{p}<0.05)$.

Conflict of Interests: The authors of this paper declare that he has no financial or personal relationships with individuals or organizations that would unacceptably bias the content of this paper and therefore declare that there is no conflict of interests.

Source of Funding: The authors have no sources of funding, so it is self-funding research.

Ethical Approve: We declare that the study does not need ethical approval.

\section{References}

1. Perić, Lidija; ŽIKIĆ, D.; LUKIĆ, Miloš.
Application Of Alternative Growth Promoters In Broiler Production. Biotechnology In Animal Husbandry, 2009, 25.5-6-1: 387-397.

2. MELLOR, S., Et Al. Antibiotics Are Not The Only Growth Promoters. World Poultry, 2000, 16.1: 1415.

3. TALALAY, Paul; FAHEY, Jed W. Phytochemicals From Cruciferous Plants Protect Against Cancer By Modulating Carcinogen Metabolism. The Journal Of Nutrition, 2001, 131.11: 3027S-3033S.

4. ZEINAB, M. A. Using Egyptian Eruca Sativa Seed Meal In Broiler Rations With Or Without Microbial Phytase. Egyp. J. Nutr. And Feed, 2003, 98-114.

5. CHEW, Boon P., Et Al. Dietary B-Carotene Stimulates Cell-Mediated And Humoral Immune Response In Dogs. The Journal Of Nutrition, 2000, 130.8: 1910-1913.Bendich, A. (1989). Carotenoids 
And The Immune Response. J. Nutr., 119:112-115.

6. LEE, K. W., Et Al. Growth Performance, Intestinal Viscosity, Fat Digestibility And Plasma Cholesterol In Broiler Chickens Fed A Rye-Containing Diet Without Or With Essential Oil Components. Int. J. Poult. Sci, 2004, 3.9: 613-618.

7. ERTAS, Osman Nihat, Et Al. The Effect Of An Essential Oil Mix Derived From Oregano, Clove And Anise On Broiler Performance. International Journal Of Poultry Science, 2005, 4.11: 879-884.

8. VARGA, Jolán, Et Al. Study Of Some Agrotehnological Characteristics Of Rocket (Eruca Sativa Mill). Bulletin Of University Of Agricultural Sciences And Veterinary Medicine Cluj-Napoca. Horticulture, 2009, 66.1: 677.

9. ALAM, M. Sarwar, Et Al. Eruca Sativa Seeds Possess Antioxidant Activity And Exert A Protective Effect On Mercuric Chloride Induced Renal Toxicity. Food And Chemical Toxicology, 2007, 45.6: 910-920.

10. HUSSEIN, Jihan, Et Al. Antihepatotoxic Effect Of Eruca Sativa Extracts On Alcohol Induced Liver Injury In Rats. Journal Of American Science, 2010, 6.11: 381-389.

11. KHOOBCHANDANI, M., Et Al. Antimicrobial Properties And Analytical Profile Of Traditional Eruca Sativa Seed Oil: Comparison With Various Aerial And Root Plant Extracts. Food Chemistry, 2010, 120.1: 217-224.

12. GULFRAZ, Muhammad, Et Al. Phytochemical Analysis And Antibacterial Activity Of Eruca Sativa Seed. Pak. J. Bot, 2011, 43.2: 1351-1359.

13. SNYDER, D. B., Et Al. Rapid Serological Profiling By Enzyme-Linked Immunosorbent Assay. III. Simultaneous Measurements Of Antibody Titers To Infectious Bronchitis, Infectious Bursal Disease, And Newcastle Disease Viruses In A Single Serum Dilution. Avian Diseases, 1984, 12-24.

14. SPSS (1998). Statistical Package For Social Sciences, Chicago, U.S.A.

15. STEEL, R. G. D.; TORRIE, J. H.; DICKEY, D. A. Principles And Procedures Of Statistics: A Biometrical Approach Mcgraw-Hill. New York, 1980.
16. LEE, K.-W., Et Al. Effects Of Dietary Essential Oil Components On Growth Performance, Digestive Enzymes And Lipid Metabolism In Female Broiler Chickens. British Poultry Science, 2003, 44.3: 450457.

17. JANG, I. S., Et Al. Influence Of Essential Oil Components On Growth Performance And The Functional Activity Of The Pancreas And Small Intestine In Broiler Chickens. Asian-Australasian Journal Of Animal Sciences, 2004, 17.3: 394-400.

18. JAMROZ, D.; KAMEL, C. Plant Extracts Enhance Broiler Performance. In Non-Ruminant Nutrition: Antimicrobial Agents And Plant Extracts On Immunity, Health And Performance. 2002.

19. BOtSOGLOU, N. A., Et Al. Effect Of Dietary Oregano Essential Oil On Performance OfChickens And On Iron-Induced Lipid Oxidation Of Breast, Thigh And Abdominal Fat Tissues. British Poultry Science, 2002, 43.2: 223-230.

20. CROSS, D. E., Et Al. The Effect Of Herbs And Their Associated Essential Oils On Performance, Dietary Digestibility And Gut Microflora In Chickens From 7 To 28 Days Of Age. British Poultry Science, 2007, 48.4: 496-506.

21. OSMAN, M.; AMBER, K. H.; MAHMOUD, M. A. Response Of Broiler Chicks Performance To Partial Dietary Inclusion Of Radish, Rocket And Parsley Cakes. Egypt. Poult. Sci, 2004, 24: 429446.

22. MITRUKA, Brij M., Et Al. Clinical Biochemical And Hematological Reference Values In Normal Experimental Animals. Clinical Biochemical And Hematological Reference Values In Normal Experimental Animals., 1977.

23. Farag, M.E.,. Influence Of Using Some Medicinal Plants As Feed Additives On The Performance Carcass Characteristics And Blood Constituents Of Grown Male Gimmizah Chickens. M. Sc. Thesis, Fac. Agric. (Saba Basha), Alex. Univ. 2007

24. Teymouri Zadeh, Z. SH. Rahimi_, M.A. Karimi Torshizi, R. Omidbaigi .,Iranian Journal of Medicinal and Aromatic Plants., 2009; 25,2 